Journal of Balkumari College

ISSN : 2467-9321 Website: http://www.nepjol.info/index.php/jbkc

Volume : 9, Issue : 1, June 2020, Page No.: 41-47

\title{
Managerial Perceptions on Internal Marketing and Employee Commitment in Nepal
}

\author{
Dr. Prakash Shrestha* \\ Lecturer \\ Nepal Commerce Campus \\ Tribhuvan University
}

\begin{abstract}
The major purpose of this study is to examine the managerial perceptions on internal marketing and employee commitment in Nepal. This is a qualitative research in nature. It covers management-level employees of covers 30 organizations (including 14 commercial banks and 16 insurance companies) of Nepal. This study is based on discussions with 30 managers ((division chiefs, branch managers, human resource managers, department heads, IT managers, branch managers, officers and managers) of Nepalese commercial banks and insurance companies by using semi-structured interviews and discussions. The results of present study show that the managers are conscious about internal marketing and employee commitment in their organizations. They also realized the important factor of these components. It is suggested that management should be aggressively engaged in internal marketing to arrive at a synergy of satisfied employees and promoted employee commitment. Committed, satisfied and competent employees will make a better impression on customers, benefiting the organization as a whole.
\end{abstract}

Key Words: Management, Perception, Internal marketing, Employee commitment, Commercial banks, Insurance companies.

\section{INTRODUCTION}

Internal marketing is human resource philosophy based on marketing concept. This marketing views the employee inside organization as an internal customer, jobs as internal products and holds the view that all employee in an organization serve both customer and supplier even in the event where one or both of these are internal colleagues. Internal marketing has become one of the foremost concerns for many organizations (Lean, 2005). Recently, internal marketing has become an important subject in an organization (Gronroos, 1981, 1985; Barnes, 1989; Piercy, 1995; Ahmed and Rafiq, 2003).

According to Rafiq and Ahmed (1993), evolution of internal marketing started with the concept of employee satisfaction by treating employees as customer and jobs as products (Berry, 1981), to market orientation (Gronroos, 1985), the use of internal marketing in implementing of external marketing programmes (Piercy and Morgan, 1991), and extension of internal marketing to the implementation of any functional strategies (Rafiq and Ahmed, 1993).

Furthermore, Foreman and Money (1995) argued that market orientation intended to "create a flexible and responsive internal environment, and nurtures common values and behavior which reflect organizational goals and its synergy with the marketplace". Although there are many literatures, yet there is not much systematic work done on how internal marketing actually works in practice. Majority of the studies on internal marketing are conceptual in nature. Till date, most of the empirical studies focus mainly on the service providers, especially in the healthcare, financial and professional services (Gronroos, 1981; Gummesson, 2000; Schlesinger and Heskett, 1991). It is identified in the literature that when scholars talk about internal marketing, they will automatically relate to market orientation. For example, according to Gronroos (1985), internal marketing is concerned with engaging in marketoriented management, in which marketing is not a function but rather a way of doing business (Gronroos, 1985).

Successful organizations are those that integrate efficient and effective management in internal and external dimensions through external customer relationship management and enhancement of organizational commitment

* Corresponding author: mrpraksahshrestha@gmail.com 
among internal customers (Akinyele, 2008). The internal marketing paradigm is a mechanism for the managers to analyze the organizational issues which need to be addressed in implementing marketing strategies. Also it can help to establish an important framework of legitimacy for new directions and transformations and accommodate the constant process of change management and knowledge development (Tandan, 2018). Many studies show the positive relationship between internal marketing and employee commitment. Hence, this study shows the managerial perceptions on various aspects of internal marketing including understanding and differentiation of reward system, career opportunities, training and development, inter-functional coordination, communication and participation as well as employee commitment of banking and insurance companies of Nepal.

\section{OPERATIONAL DEFINITIONS OF THE TERMS USED IN THIS STUDY}

Several definitions have been applied to maintain the uniformity and flows of the research. The operational definitions of key terms are presented in the following table:

Table 1: List and Definitions of Key Terms

\begin{tabular}{|c|c|c|}
\hline Terms & Core concept & Researcher(s) \\
\hline Internal Marketing & $\begin{array}{l}\text { It is a planned effort using marketing -like approach to overcome } \\
\text { organizational resistance to change and to align, motivate and } \\
\text { inter-functionally coordinate and integrate employees towards the } \\
\text { effective implementation of corporate and functional strategies in } \\
\text { order to deliver customer satisfaction through a process of creating } \\
\text { motivated and customer - oriented employees. }\end{array}$ & $\begin{array}{l}\text { Rafiq and Ahmed } \\
\qquad(2000)\end{array}$ \\
\hline Reward System & $\begin{array}{l}\text { It is a key factor toward employee overall satisfaction with the } \\
\text { company. The feeling of not being recognized for a job well done } \\
\text { is likely to evoke a negative attitude toward the organization. }\end{array}$ & $\begin{array}{c}\text { Tornow and Wiley } \\
\text { (1991) }\end{array}$ \\
\hline $\begin{array}{c}\text { Career } \\
\text { Opportunities }\end{array}$ & $\begin{array}{l}\text { Younger employees are significantly more likely to leave their } \\
\text { organizations than older employees are. Older employees have } \\
\text { more difficulty finding new jobs, because they suffer from negative } \\
\text { stereotyping and age discrimination than younger ones do. }\end{array}$ & $\begin{array}{l}\text { Posthuma and } \\
\text { Campion (2009) }\end{array}$ \\
\hline $\begin{array}{l}\text { Training and } \\
\text { Development }\end{array}$ & $\begin{array}{l}\text { It refers to the acquisition of knowledge, skills and competencies } \\
\text { as a result of teaching practical knowledge that relate to specific } \\
\text { useful competencies. }\end{array}$ & Reilly (1979). \\
\hline $\begin{array}{l}\text { Inter-functional } \\
\text { Coordination }\end{array}$ & $\begin{array}{l}\text { He dealt with cross-functional coordination. Cross-functional } \\
\text { coordination causes internal functional boundaries to lose meaning. } \\
\text { He determined six approaches: } \\
\text { Unify holistic strategy, organization structure or management } \\
\text { hierarchy, process management and systems, information systems } \\
\text { and information systems management, informal social systems and } \\
\text { culture and employees' selection and promotion. }\end{array}$ & Shapiro (1987) \\
\hline Communication & $\begin{array}{l}\text { It describes how organizations have necessarily had to think } \\
\text { more now than in the past about how they communicate with } \\
\text { their employees through, what is also often called, "internal } \\
\text { communication". }\end{array}$ & Argenti (1998) \\
\hline Participation & $\begin{array}{l}\text { It represents the combination of task-related practices, which } \\
\text { aim to maximize employees' sense of involvement in their work, } \\
\text { and human resource management practices that aim to maximize } \\
\text { employees' commitment to the wider organization. }\end{array}$ & $\begin{array}{c}\text { Bhatti, Nawab and } \\
\text { Akbar (2011) }\end{array}$ \\
\hline $\begin{array}{c}\text { Employee } \\
\text { Commitment }\end{array}$ & It is a physiological state that binds the individual to the organization. & $\begin{array}{c}\text { Allen and Meyer } \\
\text { (1990) }\end{array}$ \\
\hline
\end{tabular}




\begin{tabular}{|c|l|c|}
\hline $\begin{array}{c}\text { Affective } \\
\text { Commitment }\end{array}$ & $\begin{array}{l}\text { It is an employee's emotional attachment, identification with, and } \\
\text { involvement in an organization. }\end{array}$ & $\begin{array}{c}\text { Allen and Meyer } \\
(1990)\end{array}$ \\
\hline $\begin{array}{c}\text { Continuance } \\
\text { Commitment }\end{array}$ & $\begin{array}{l}\text { It refers to commitment based on the costs that the employee } \\
\text { associates with leaving the organization (due to the high cost of } \\
\text { leaving). }\end{array}$ & $\begin{array}{c}\text { Allen and Meyer } \\
(1990)\end{array}$ \\
\hline $\begin{array}{c}\text { Normative } \\
\text { Commitment }\end{array}$ & $\begin{array}{l}\text { It is an employee's feelings of obligation to remain with the } \\
\text { organization. It is also known as moral commitment. }\end{array}$ & $\begin{array}{c}\text { Allen and Meyer } \\
(1990)\end{array}$ \\
\hline
\end{tabular}

\section{RESEARCH METHODS}

This study focuses on getting information relating to managerial perceptions on internal marketing dimensions and employee commitment. It also gives focus on some of the demographic. This is a qualitative research in nature. This study is based on discussions with managers of Nepalese banks and insurance companies by using semi-structured interviews. The participants' semi-structured interviews are conducted with a fairly open framework which allow for focused, conversational and two-way communication. During the research data collection process, 30 managers/chiefs (division chiefs, branch managers, human resource managers, department heads, IT managers, branch managers, officers and managers) representing their organizations have been involved in discussions about situations of workplace. It covers management-level employees of covers 14 commercial banks and 16 insurance companies of Nepal. Key informants from the community (banking and insurance) under the study regarding internal marketing and employee commitment issues are "privileged witnesses because of their position, activities or responsibilities have a good understanding of the problem to be explored". The following table presents a summary of participants position/level, experience years in the current position and organizations where they involved now:

Table 2: Semi-Structured Participants Interviews and Focus Groups Discussion

\begin{tabular}{|c|c|c|c|c|}
\hline S.N. & Name of Organizations & Symbol & Position/Level & $\begin{array}{l}\text { Experience years in } \\
\text { the current position }\end{array}$ \\
\hline 1. & Nepal Bank Ltd. & Organization A & Division chief & 4 years \\
\hline 2. & Agriculture Development Bank Ltd. & Organization B & Division chief & 5 years \\
\hline 3. & Nabil Bank Ltd. & Organization $\mathrm{C}$ & Branch manager & 6 years \\
\hline 4. & Nepal Investment Bank Ltd & Organization D & Branch manager & 7 years \\
\hline 5. & Nepal SBI Bank Ltd. & Organization E & HR Manager & 6 years \\
\hline 6. & Everest Bank Ltd. & Organization F & Branch manager & 3 years \\
\hline 7. & Bank of Kathmandu Ltd. & Organization $\mathrm{G}$ & HR manager & 4 years \\
\hline 8. & Machhapuchhre Bank Ltd. & Organization $\mathrm{H}$ & IT manager & 5 year \\
\hline 9. & Kumari Bank Ltd. & Organization I & Branch manager & 6 years \\
\hline 10. & Siddhartha Bank Ltd. & Organization $\mathrm{J}$ & HR manager & 5 years \\
\hline 11. & Prime Commercial Bank & Organization $\mathrm{K}$ & HR manager & 3 years \\
\hline 12. & Pravhu Bank Ltd. & Organization L & Manager & 5 years \\
\hline 13. & NMB Bank Ltd. & Organization M & HR manager & 4 years \\
\hline 14. & Himalayan Bank Ltd. & Organization $\mathrm{N}$ & Manager & 8 years \\
\hline 15. & Rastriya Beema Samsthan & Organization $\mathrm{O}$ & Department head & 4 years \\
\hline 16. & Nepal Insurance Company & Organization $\mathrm{P}$ & Branch manager & 3 years \\
\hline 17. & National Insurance Company Ltd. & Organization Q & Manager & 4 years \\
\hline 18. & National Life Insurance Company Ltd. & Organization $\mathrm{R}$ & Branch manager & 6 years \\
\hline 19. & Premier Insurance Company & Organization $\mathrm{S}$ & Manager & 4 years \\
\hline 20. & Everest Insurance Company & Organization $\mathrm{T}$ & Manager & 6 years \\
\hline
\end{tabular}




\begin{tabular}{|c|l|c|c|c|}
\hline 21. & Neco Insurance Ltd. & Organization U & HR Manager & 7 years \\
\hline 22. & Sagarmatha Insurance Company Ltd. & Organization V & Department head & 3 years \\
\hline 23. & Alliance Insurance Company Ltd & Organization W & Manager & 5 years \\
\hline 24. & NB Insurance Company & Organization X & HR Manager & 5 years \\
\hline 25. & Life Insurance Corporation & Organization Y & Manager & 6 years \\
\hline 26. & American Life Insurance Company & Organization Z & Manager & 4 years \\
\hline 27. & Nepal Life Insurance Company Ltd. & Organization AA & Manager & 5 years \\
\hline 28. & Prudential Insurance Company Ltd. & Organization AB & Manager & 3 years \\
\hline 29. & Shikhar Insurance Company & Organization AC & Officer & 5 years \\
\hline 30. & Gurans Life Insurance Company Ltd. & Organization AD & Officer & 6 years \\
\hline
\end{tabular}

\section{RESULTS AND FINDINGS}

Internal marketing is a philosophy of human resources management. It is relevant to all types of organizations and especially critical for people, intensive industry such as banking and insurance sectors. The current research makes important contributions to the field of internal marketing in Nepalese commercial banks and insurance companies and sheds light on several internal marketing dimensions and employee commitment. When management takes care of all these dimensions of internal marketing they will enhance the commitment of the employees. Therefore, some human resource (HR) managers, division chiefs, and management have explained about the questions (see appendix) which are in following manner:

\section{Management Perception on Internal Marketing}

This section presents some of the important managerial perceptions regarding internal marketing. Some managers have expressed that:

"Human resource management is very important for development of any organization. This century is about generating human capital for which mobilization of human resource in accurate way is must. Thus, Nepalese "A" class commercial banks and insurance companies utilize capable employee to its fullest to increase the income of the bank and insurance companies and increase the level of customer satisfaction" (Division chief, HR manager and Department head of organizations B, J and O).

The discussion with also highlight that:

"Yes, I have heard the term internal marketing and employee commitment. I think staff internally needs to be aware of the product and services as well as policies are available. So, for us as an organization we need to be able to sell to our own members of staff so all of our staff knows what we can do as a company for our clients". (HR manager of organization E)

"Yes, I am familiar with internal marketing of my organization. It means focus of internal marketing on the relationship between the employee and the organization. Although in our organization it is not so develop, I have a bit idea about internal marketing. So, I have been trying to implement internal marketing tools in our organization” (Branch manager, HR manager and Manager of $\mathrm{C}, \mathrm{K}$ and $\mathrm{N}$ ).

In terms of reward following managers highlight that:

"I'm happy with my remuneration and reward system" (Division chief, Division chief, Branch manager and Manager of Organizations A, B, D and N).

Similarly, "if we use career opportunity, inter-functional coordination, communication and participation in the organization than there will be positive impact on employee commitment" (Branch manager, Manager, Branch manager and of Organizations F, L, R and AD).

Likewise, training provides practical knowledge to the employee, so it definitely has positive impact on employee commitment (Division chief, HR manager, Manager and Officer of Organizations B, M, W and AC). 
Some managers also highlighted that:

"Yes, there is link between job status and employee commitment" (HR Manager, Branch manager, Manager and HR manager of Organizations E, I, W and X).

"Employee job involvement is important to run any organization smoothly" (Branch managers, and Managers of Organizations C, F, L and Y).

"Yes, I have been given this right by rules and regulations of our organization" (Branch manager, managers, and Branch manager of organizations $\mathrm{C}, \mathrm{L}, \mathrm{Q}$ and $\mathrm{R}$ ).

"By using different types of internal marketing tools I would you like to improve our system, mechanism which will help to take competitive advantage in the exiting market" (Branch manager, HR manager, Department head and Manager of organizations I, M, O and S).

In terms of status of internal marketing some managers highlighted that:

"The status of internal marketing in my organization is not well operating but we are trying to operate it as soon as possible in beneficial way. Thus, we all are cooperating to upgrade the status of internal marketing in our organization" (HR Managers and Managers of organizations E, J, X and AA).

\section{Management Perception on Employee Commitment}

This section presents some of the important managerial perceptions regarding employee commitment. Some managers have expressed that:

"I am familiar with the term of employee commitment" (Branch manager and Managers, of D, Z and AA).

Regarding relationship between internal marketing and employee commitment some managers highlighted that:

Yes, in practice there is perfect correlation between internal marketing and employee commitment in our organization (HR Managers and Managers of Organizations E, J, X and AA).

Some managers also highlighted that:

“Employees' job performances enhance employee commitment. Motivated, talented, knowledgeable and committed employee helps to promote employee commitment and the status of an organization. So, job performance is much more important for any organization" (Division chief, Branch managers and Manager of Organizations B, I, P and Z).

The discussion with managers and employees also highlight that:

"Employees are concerned with the internal marketing practices in their organizations. They are paid a rate higher than their industry average. So, reward system has a positive effect on employee commitment." (Branch manager, HR Manager and Managers of organizations D, E, N and X)

Some HR managers in Organizations J, K and Q regard employees as the most important assets of their organizations. They said the following words:

"In fact, people are the success factor of our organization. So, the demands of internal customer are being fulfilled in my organization"

"Our people are at the heart of our business".

In term of importance of demographic characteristics some managers highlighted:

"All demographic characteristics are important in our organization because age, sex, marital status, academic qualification, work experience, job level, sector and pattern of organization has been playing significant role for development of employee commitment in our bank and insurance company" (HR manager, Branch managers and Department head of Organizations G, I, S and V). 


\section{CONCLUSIONS}

Internal marketing plays dynamic role in the Nepalese financial sector. It is an important business promotion strategic tool for banks and insurance companies of Nepal. So, the internal marketing remains an important business tactic that contributes meaningfully to the welfare of the banks and insurance companies employees who play the dynamic role of inner customers in their organizations thereby enhancing employee commitment in these companies. Internal marketing helps to achieve the employee's professional competence and employee commitment and promotion of the whole outcomes of the companies. Based on these various opinions and perceptions, it appears that the managers are conscious about internal marketing and employee commitment in banking and insurance sector of Nepal. They realized the important factor of these components. Therefore, management should be aggressively engaged in internal marketing to arrive at a synergy of satisfied employees and promoted employee commitment. Committed, satisfied and competent employees will make a better impression on customers, benefiting the organization as a whole.

\section{REFERENCES}

Ahmed, P. K., \& Rafiq, M. (2003). Commentary internal marketing issues and challenges. European Journal of Marketing, 37(9), 1177-1186.

Akinyele, S. T. (2008). An empirical analysis of internal marketing on organizational commitment: A study of banks in Lagos-Nigeria. School of Business, Covenant University, Ota-Nigeria.

Allen, N. J., \& Meyer, J. P. (1990). The measurements and antecedents of affective, continuous and normative commitment to the organization. Journal of Occupational Psychology, 63(1), 1-18.

Argenti, P. A. (1998). Corporate Communication. 2nd ed. Boston MA: McGraw-Hill.

Barnes, J. G. (1989). The role of internal marketing: if the staff won't buy it why should the customer?. Irish Marketing Review, 4(2), 11-21.

Berry, L. L. (1981). The employee as customer. Journal of Retail Banking, 3(1), 25-9.

Bhatti, K., Nawab, S., \& Akbar, A. (2011). Effect of Direct Participation on Organizational Commitment. International Journal of Business and Social Science, 2(9), 15-23.

Foreman, S.K., \& Money, A.H., (1995). Internal marketing: concepts, measurement and application. Journal of Marketing Management, 11(8), 755-768.

Grönroos, C. (1981). Internal marketing-an integral part of marketing theory. In: Proceedings of the American Marketing Association's Services Marketing Conference. Chicago, IL, 236-238.

Grönroos, C. (1985). Internal marketing: theory and practice. In: Proceedings of the American Marketing Association's Services Marketing Conference, Chicago, 41-47.

Gummesson, E. (2000). Internal marketing in the light of relationship and network organisations, Internal Marketing Routledge, New York, p. 27.

Lean, C. P. (2005). The relationship between internal marketing, job satisfaction, organization commitment and market orientation: A study on manufacturing companies in Northern region of Malaysia. Unpublished Masters thesis, Universiti Sains Malaysia.

Piercy, N. (1995). Customer satisfaction and the internal market: marketing our customers to our employees. Journal of Marketing Practice: Applied Marketing Science, 1(1), 22-44.

Piercy, N., \& Morgan, N. (1991). Internal marketing. The missing half of the marketing programme, Long range planning, 24(2), 82-93.

Posthuma, R.A., \& Campion, M.A. (2009). Age stereotypes in the workplace: Common stereotypes, moderators, and future research directions. Journal of Management, 35(1), 158-188. http://dx.doi.org.

Rafiq, M., \& Ahmed, P. K. (1993). Scope of internal marketing: Defining the boundary between marketing and human resources management, Journal of Marketing Management, 9(3), 219-232.

Rafiq, M., \& Ahmed, P. K. (2000). Advances in the internal marketing concept: Definition, synthesis and extension, Journal of Services Marketing, 14(6), 449-462.

Reilly, E. W. (1979). The Work of Top Management, Lecture Delivered to the Participants in the Management Development Program, Columbia University. 
Schlesinger, L. A., \& Heskett, J. L. (1991). Breaking the cycle of failure in services. Sloan Management Review $32(3), 17-28$.

Shapiro, D. L. (1987). Interactional fairness judgments: The influence of causal accounts. Social Justice Research, l(2), 199-218.

Tandan, S. (2018). Internal marketing and employee commitment in Nepalese corporate sector. Unpublished Ph.D. dissertation submitted to the Faculty of Management, Tribhuvan University, Kathmandu, Nepal.

Tornow, W., \& Wiley, J. (1991). Service quality and management practices: a look at employee attitudes, customer satisfaction, and bottom-line consequences, Human Resource Planning, 14(2), 105-115.

\section{APPENDIX}

Discussion Questions for Managerial Perceptions on Internal Marketing and Employee Commitment in Nepal 1. What is your opinion about 'human resource management' in your organization?

2. Are you familiar with the internal marketing of your organization?

3. How is the status of internal marketing in your organization?

4. Why do you thing employee job involvement is important?

5. Why is job performance important for organization?

6. Do you have the authority to control and manage your staff?

7. What mechanism would you like to improve in your organization?

8. Are you familiar with the employee commitment?

9. Are the demands of employees (internal customer) being fulfilled in your organization?

10. Does a reward system have a positive effect on employee commitment?

11. Does a career opportunity have a positive effect on employee commitment?

12. Does an inter-functional coordination have a positive effect on employee commitment?

13. Do training and development have a positive effect on employee commitment?

14. Does communication system have a positive effect on employee commitment?

15. Does the participation of employees in your organization have a positive effect on employee commitment?

16. Is there any relation between internal marketing and employee commitment in your organization?

17. Which demographic characteristics are important in terms of employee commitment?

18. Do you find any link between job status and employee commitment? 